\title{
The Prevalence of Writing Across the Curriculum in Collegiate Aviation Flight Education
}

\author{
Lorelei E. Ruiz \\ Southern Illinois University Carbondale
}

\begin{abstract}
The purpose of this paper is to report on the use of writing assignments and the prevalence of Writing Across the Curriculum (WAC) in collegiate aviation flight programs. Researchers report a variety of results with the incorporation of writing and speaking assignments in different fields, but similar study in aviation is not well reported. Of 115 University Aviation Association institutions surveyed, 37 responded to a battery of questions regarding the use of writing assignments in their aviation flight programs and WAC. While the majority of respondents indicate that their institution does not have an established WAC program, collegiate aviation flight programs do employ a variety of communicationfocused courses to address communication training and assignments to teach/practice communication skills. Additionally, the majority of responding institutions indicate that writing assignments are required.
\end{abstract}

\section{INTRODUCTION}

In higher education, there is a movement to improve students' communication and critical thinking skills through a program known as Communication Across the Curriculum (CAC). CAC combines the earliest forms of Writing Across the Curriculum (WAC) and Speaking Across the Curriculum (SAC), two movements dating back to the 1970's (Fulwiler \& Young, 1997; Schneider, 1999), with other forms of communication.

Recently, practitioners and educators are proposing a variety of across-the-curriculum programs to address students' lack of communication skills and to improve thought processes (Riley, 1996; Schneider, 1999). Morello (2000) provides a description of speaking across the curriculum programs, while Bellon (2000) supports the notion of a debate across the curriculum program for improving students' skills. Addressing electronic communication across the curriculum, Rea, Hoger, and Rooney (1999, p. 93) note that "[t]echnlogy and communication are fields that transcend disciplinary boundaries and permeate students' functioning in all of their learning experiences."

McLeod (1992) defines WAC "as a comprehensive program that transforms the curriculum, encouraging writing to learn and learning to write in all disciplines"(p. 5). It is based on the assumption that "writing and thinking are closely allied, that learning to write well involves learning particular discourse conventions, and that, therefore, writing belongs in the entire curriculum, not just in a course offered by the English department" (McLeod, 1992, p. 6). The purpose of this article is to report on the use of writing assignments and the prevalence of WAC in collegiate aviation flight programs.

\section{COMMUNICATION IN AVIATION EDUCATION}

The 'General Education Curriculum Criteria' for accreditation by the Council on Aviation Accreditation (CAA) (Council on Aviation Accreditation, 2003, p.9-10) include "studies in communications which emphasize competency in written and verbal communication skills... and demonstrated competence in using computers for problem-solving". English composition, speech, and computer courses have a place in higher education. CAC focuses on the incorporation of these skills in other classes, e.g. Human Factors, Regulations, Weather, etc., allowing for continued practice.

Currently in the aviation industry, established Crew Resource Management training programs incorporate a similar approach to communication training. According to Kanki and Palmer (1993), communication may

(1) constitute a topic on its own (i.e., a communication module), (2) be incorporated into every other topic of the 
curriculum (i.e., interwoven into every other module), and/or (3) be treated as a special topic, such as one that focuses on the interface between teams (e.g., pilotATC, pilot-flight attendant, pilot-dispatch coordination). (p. 131)

Authentic writing, speaking, and/or computer assignments can be applied in a variety of courses, allowing educators to better prepare students for the types of communication they will encounter in industry.

\section{TYPES OF ASSIGNMENTS}

Research in the area of WAC specifically is reported in such fields as medicine, finance, economics, business, psychology, physics, mathematics, chemistry, history, and philosophy. Instructors have used such techniques as assigning poetry writing in psychology (Gorman, Gorman, \& Young, 1986), analysis of published articles and peer review of lab reports in biology (Flynn, McCulley, \& Gratz, 1986), and use of student journals in mathematics (Selfe, Peterson, \& Nahrgang, 1986). Garner (1994) reports the effective use of microthemes in accounting, with steady improvement in a student's writing quality as the term progresses.

Specifically in aviation, there is published material regarding the use of case studies in coursework. Lutte (1996) reported the use of case analysis as the primary means of course delivery for a sixteen-week course, with the following course objectives:

1. develop critical thinking skills;

2. study past and present issues in aviation;

3 . be able to communicate opinions and support them with documented information;

4. develop an ability to listen to other's opinions and keep an open mind in a discussion or debate;

5. writing clear and concise analysis based on case materials; and

6. develop team building skills. (p. 15)

The objectives as stated are congruent with the goals of CAC.

\section{WRITING ACROSS THE CURRICULUM APPLICATIONS}

Southern Illinois University at Carbondale's (SIUC) CAC program began as a WAC program, but was quickly expanded to allow for the inclusion of oral, visual, and electronic communication ("Communication", 1999). Focusing on the writing component of CAC, courses identified as writing intensive courses in the College of Applied Sciences and Arts at SIUC require that students produce a minimum of fifteen pages of written material meeting certain criteria (Isberner, 2000). Assignments are classified as either learning-towrite or writing-to-learn. The former focuses on the composition of authentic written products, assignments modeled after the types of writing that students may be expected to produce upon entering the workforce. The latter is based on the idea that through writing, students learn. Examples of these assignments might include inclass writing and journals, designed with the purpose of using the student's writing to enhance the student's own learning instead of test knowledge gained (McLeod \& Maimon, 2000) Such products may well be more informal than the learning-to-write assignments.

\section{RESEARCH QUESTIONS}

For this paper, the researcher wished to determine how and to what extent communication training, particularly Writing Across the Curriculum, is being addressed in collegiate aviation. The research questions to be answered included:

1. In what ways are colleges and universities addressing communication training for aviation students?

2. How prevalent are writing assignments in collegiate aviation flight training?

3. How prevalent is Writing Across the Curriculum in collegiate aviation flight training?

\section{METHODOLOGY}

To answer these research questions, a target population was identified using the 
University Aviation Association's (UAA) 20012002 UAA Institutional Members mailing labels list. Of 119 total institutions, 115 institutions, those located within the United States and its territories, were chosen for this study.

A cover letter, four-page survey, and postage-paid return envelope were sent to each institution's contact person named on the mailing label. The three-part survey requested basic demographic information, general information related to existing communication training within aviation programs, and WAC-specific information. Green paper was used for printing the surveys. King, Pealer and Bernard (2001) note some studies that suggest an increased response rate when using green paper. Four weeks after the initial mailing, follow-up letters were sent to all of the institutions.

To check the validity of the survey instrument, it was distributed to two experts for their review. Their suggestions were incorporated into the instrument. The survey was then given to four colleagues who teach or have taught ground school courses in a flight-training program to test the instrument for reliability.

\section{Results and Analysis}

Of the 115 institutions contacted, 37 (32\%) returned completed surveys. The low overall response rate can only in part be attributed to the fact that not all UAA-member institutions offer aviation flight training. A review of the Collegiate Aviation Guide (CAG) (Kitely, 1999) and supplementary searches on the World Wide Web yielded the following information. Of the surveyed institutions, 92 do offer some level of flight training, and 22 do not. The researcher was unable to determine whether the remaining one institution offers flight training. This yields a response rate of $40 \%$ for surveyed institutions known to offer flight training.

According to Babbie (1992), a 50\% response rate is generally recommended for mail surveys sampling a population, but he admits that this is a rough guide. Also, this study surveyed the entire population and not a sample. To determine the possibility of response bias, analysis of various characteristics of the responding institutions was attempted utilizing information gleaned from the CAG, the World Wide Web, and demographic information reported by respondents. Due to incomplete information reported in the CAG and the changing membership in the UAA, it was difficult to exactly match the surveyed population. Only 62 of the surveyed 2001-2002 institutions had information reported in the $1999 \mathrm{CAG}$, and the information given on these institutions was not necessarily complete. Therefore, internal analysis for response bias was not completed.

Basic demographic data follows, and the research questions are addressed. Statistics used to interpret the data include descriptive statistics (frequency counts and means) and the Pearson Chi-Square. An alpha level (a) of .05 was used to determine significance in statistical tests.

\section{Demographics}

The 37 respondents were either department chairs (25) or senior faculty members (12) at their institutions. One had earned an Associate degree, six a Bachelor degree, 17 a Masters degree, 11 a $\mathrm{PhD} / \mathrm{EdD}$, and one indicated Specialist. One respondent did not indicate an education level. They averaged 8 years in their current position, with 16 having been employed in the current position up to 5 years, 11 from 6 to 10 years, 4 from 11 to 15 years, 2 from 16 to 20 years, and 4 with more than 20 years.

Institutions represented include both 2year colleges (17) and 4-year universities (21). One respondent indicated both, explaining the apparent extra response. This respondent was excluded from inferential statistical analysis involving institutional affiliation to meet requirements for independence. Institutional student enrollments reported by the respondents range from 100 students to 55,000 students, and flight-training enrollments range from 10 students to 300 students. Associate degrees in aviation are offered by 18 of the institutions, 21 institutions offer a bachelors degree, 6 offer a masters degree and 1 reported offering a $\mathrm{PhD} / \mathrm{EdD}$.

Respondents were asked to indicate the number of single-engine aircraft, multiengine aircraft, FTD/simulators, and PCATDs their institutions operate. Eighteen respondents (49\%) indicated the actual number while the rest simply checked which types of equipment were available. For that reason, only the number of responding 
institutions utilizing a certain type of equipment is reported here. Equipment utilized in flight training by the responding institutions include singleengine aircraft (32), multi-engine aircraft (27), FTD/simulators (33), PCATDs (22), and one institution reported not using any of the listed equipment.

\section{Research Question 1}

In what ways are colleges and universities addressing communication training for aviation students?

Respondents were asked to indicate which courses from a list of communication-focused courses were either required general education, required aviation, or elective courses in the institution's flight training program. Table 1 indicates the responses given. Respondents report the use of a variety of courses in their institutions' aviation and general education programs; many institutions require more than one communication course. In addressing written communication, 30 require a basic or freshman grammar course, 36 require basic or freshman composition, and 22 require advanced composition. To address oral communication, 30 require a speech course, 11 require an interpersonal communication course, and 1 requires a debate course. A basic computing course is required by 29 of the responding institutions. In several cases, respondents indicate that their institution offers one or more of the above courses as electives (see Table 1). Additionally, one respondent noted in the margin that the institution included both a Principles of Communication course and a Business Communication course in its general education requirements.

Differences between two- and four-year institutions are shown in Table 2. Chi-Square analysis of the communication-focused courses was performed to determine whether either type of institution is more likely to require a course or offer it as an elective. The test yields significant differences in course offerings between the two types of institutions in the case of the advanced composition course $\left[\mathrm{X}^{2}(1, N=32)=5.203, p=\right.$ .02] and interpersonal communication course $\left[\mathrm{X}^{2}(1, N=22)=4.701, p=.03\right]$. The four-year institutions reporting an advanced composition course are much more likely (84\%) to require it than the two-year institutions (46\%). It should be noted that $54 \%$ of two-year institutions responding do offer advanced composition as an elective. Likewise, the four-year institutions reporting an interpersonal communication course are much more likely $(69 \%)$ to require it than the two-year institutions $(22 \%)$.

Within the flight training program specifically, respondents report additional coursework and assignments to address communication training in aviation. Of the 37 respondents, four indicated the use of a dedicated aviation communication/standard phraseology course, 33 indicated a communications unit within a course, 18 indicated one-on-one training, 18 indicated commercial videos, and 15 indicated self-study. Under Other, respondents indicated written and oral term projects, papers, student presentations, and technical writing courses as additional ways that the flight-training program addresses communication training. Differences between two- and four-year institutions are shown in Table 3. Chi-Square analysis yielded no statistically significant differences.

\section{Research Question 2}

How prevalent are writing assignments in collegiate aviation flight training?

Respondents were asked to indicate methods that are employed within their program to teach/practice communication skills. Written exercises were indicated by 30 respondents, while 33 indicated oral presentations, 26 indicated group exercises, 33 indicated in-class discussion, and 13 indicated computer-based exercises. Under Other, respondents indicated Internet discussion groups and web-based instruction as additional methods used to teach or practice communication skills. Differences between two- and four-year institutions are shown in Table 4. Chi-Square analysis yielded no statistically significant differences.

Respondents were further asked about the use of writing assignments in ther institution's aviation program. Specifically, the survey asked whether the program requires writing assignments in aviation courses. Two respondents indicated that their aviation courses did not require writing 
assignments, while the remaining 35 indicated that their aviation courses did require some writing assignments. Of those 35 institutions, respondents indicated that 11 programs require at least one multiple-draft assignment, and 27 indicated that their aviation programs do offer courses in which a minimum percent of the course grade is based on writing assignments. Differences between two- and four-year institutions are shown in Table 5. Chi-Square analysis yielded no statistically significant differences.

Finally, respondents were asked to indicate examples of writing assignments that faculty at their institution use in aviation courses. All respondents indicated at least one type of writing assignment. Table 6 indicates the types of writing assignments the respondents reported. Under Other, respondents indicated the use of discussion questions for seminar courses, homework questions in the textbook, lesson plans, peer evaluation of certified flight instructor candidates, research/experience reports, term papers, position papers, press releases, resumes, and policy analyses in their courses.

Chi-Square analysis reveals statistically significant differences between two- and four-year institutions for the Airport Planning Document $\left[\mathrm{X}^{2}(1, N=36)=4.91, p=.03\right]$ and the Journal writing $\left[\mathrm{X}^{2}(1, N=36)=10.80, p=.00\right]$ assignments. In both cases, the four-year institutions were more likely to require those types of writing assignments than two-year institutions.

\section{Research Question 3}

How prevalent is Writing Across the Curriculum at institutions offering collegiate aviation flight training?

Respondents were asked to indicate whether their institutions have a Writing Across the Curriculum program. Fourteen respondents reported either an established WAC program or one at some stage of development, and 23 indicated that their institutions do not have a WAC program in place. Differences between twoand four-year institutions, including a breakdown of established WAC programs versus those in development, are shown in Table 7. Chi-Square analysis does yield a statistically significant difference $\left[\mathrm{X}^{2}(1, N=36)=4.91, p=.03\right]$. A greater percentage of four-year institutions $(55 \%)$ report either an established or developing WAC program than two-year institutions (19\%). The one respondent indicating both two-year and fouryear institutional affiliations reported no WAC program.

\section{CONCLUSIONS}

Colleges and universities employ a variety of communication-focused courses to address communication training and assignments to teach/practice communication skills. Institutions indicate basic grammar, basic composition, advanced composition, speech, and basic computing, as the communication-focused courses most often required of students. Within the flight training program specifically, institutions indicate course units, one-on-one training and commercial videos as the additional coursework most often used to address communication training. Oral presentations, inclass discussion, written exercises, and group exercises were reported as the methods most often used in the programs to teach/practice communication skills.

The majority of responding institutions (35) indicate that writing assignments are required in their aviation courses. However, when asked to indicate methods employed within the program to teach/practice communication skills, only 30 institutions indicated written exercises. One reason for this may be that the writing assignments in some cases are of the writing-tolearn type, developed to enhance the student's knowledge of the subject matter rather than develop communication skills. All respondents did indicate at least one example of writing assignments their faculty use in aviation courses. Finally, ten institutions (27\% of respondents) indicate that a WAC program is in place. An additional four respondents indicate that such a program is under development. While the majority of responding institutions (27) indicate that they do not have an established WAC program, most of them do offer aviation courses that require writing assignments, and many of these courses base a percentage of the final grade on those writing assignments. 


\section{REFERENCES}

Babbie, E. R. (1992). The practice of social research. (6 ${ }^{\text {th }}$ ed.). Belmont, CA: Wadsworth Publishing Company.

Bellon, J. (2000). A research-based justification for debate across the curriculum. Argumentation \& Advocacy, 36(3), 161-175.

Communication across the curriculum at Southern Illinois University Carbondale. (1999, October 10). Retrieved February 19, 2003, from http://www.siu.edu/departments/

cac/introducing.html

Council on Aviation Accreditation. (2003). Accreditation standards manual. Auburn, AL: Author.

Flynn, E. A., McCulley, G. A., \& Gratz, R. K. (1986). Writing in biology: effects of peer critiquing and analysis of models on the quality of biology laboratory reports. In A. Young \& T. Fulwiller (Eds.), Writing across the disciplines: Research into practice (pp.68-85). Portsmouth, NH: Boynton/Cook Publishers.

Fulwiler, T., \& Young, A. (1997). The WAC archives revisited. In K. B. Yancey, \& B. Huot, (Eds.), Assessing writing across the curriculum: Diverse approaches and practices (pp. 1-6). Greenwich, CT: Ablex Publishing Corporation.

Garner, R. M. (1994). An efficient approach to writing across the curriculum: Microthemes in accounting classes. Journal of Education for Business, 69(4), 211-216.

Gorman, M. E., Gorman, M. E., \& Young, A. (1986). Poetic writing in psychology. In A. Young \& T. Fulwiller (Eds.), Writing across the disciplines: Research into practice (pp.68-85). Portsmouth, NH: Boynton/Cook Publishers.

Isberner, F. (2000). College of Applied Sciences and Arts: Communication across the curriculum writing intensive course review. Unpublished manuscript, Southern Illinois University Carbondale.

Kanki, B. G., \& Palmer, M. T. (1993). Communication and Crew Resource Management. In E. L. Wiener, B. G. Kanki, \& R. L. Helmreich, (Eds.), Cockpit Resource Management (pp. 99-136). San Diego, CA: Academic Press, Inc.

King, K. A., Pealer, L. N., \& Bernard, A. L. (2001). Increasing response rates to mail questionnaires: A review of inducement strategies. American Journal of Health Education, 32(1), 4-15.

Kitely, G. (Ed.). (1999). Collegiate aviation guide: Reference of collegiate aviation programs. Auburn, AL: University Aviation Association.

Lutte, R. K. (1996). How to use case analysis as an entire semester course in aviation. Journal of Air Transportation World Wide, 1, 13-21.

McLeod, S. \& Maimon, E. (2000). Clearing the air: WAC myths and realities. College English, 62(5), 573583. 
McLeod, S. H. (1992). Writing across the curriculum: An introduction. In S. H. McLeod \& M. Soven (Eds.), Writing across the curriculum (pp. 1-11). Newbury Park, CA: Sage Publications, Inc.

Morello, J. T. (2000). Comparing speaking across the curriculum and writing across the curriculum programs. Communication Education, 49, 99-113.

Rea, A. I., Jr., Hoger, B., \& Rooney, P. (1999). Communication and technology: Building bridges across the chasm. Business Communication Quarterly, 62(2), 92-96.

Riley, S. G. (1996). Craft meets art as professors try writing across the curriculum. Journalism \& Mass Communication Educator 50(4), 77-81.

Schneider, A. (1999). Taking aim at student incoherence. The Chronicle of Higher Education, 45(29), A16A18.

Selfe, C. L., Peterson, B. T., \& Nahrgang, C. L. (1986). Journal writing in mathematics. In A. Young \& T. Fulwiler (Eds.), Writing across the disciplines: Research into practice (pp. 192-207). Portsmouth, NH: Boynton/Cook Publishers 
Table 1

Communication Courses Offered by Responding Institutions

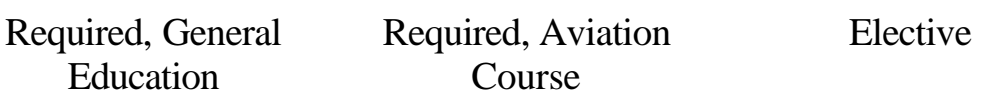

\begin{tabular}{|c|c|c|c|}
\hline Basic grammar $^{a}$ & 29 & 2 & 1 \\
\hline Basic composition $^{\mathrm{a}}$ & 35 & 2 & 0 \\
\hline $\begin{array}{l}\text { Advanced } \\
\text { composition }^{\mathrm{a}}\end{array}$ & 21 & 2 & 10 \\
\hline Speech $^{\mathrm{a}}$ & 27 & 4 & 5 \\
\hline Debate & 1 & 0 & 10 \\
\hline $\begin{array}{l}\text { Interpersonal } \\
\text { communication }\end{array}$ & 9 & 2 & 11 \\
\hline Basic computing $^{\mathrm{b}}$ & 25 & 4 & 8 \\
\hline
\end{tabular}

${ }^{a}$ One responding institution indicated the course being offered as both a required general education course and a required aviation course.

${ }^{\mathrm{b}}$ Two responding institutions indicated the course being offered as both a required general education course and an elective. 
Table 2

Communication Courses Offered: Two-year Versus Four-year Institutions

\begin{tabular}{|c|c|c|c|c|c|c|c|c|c|}
\hline \multirow[b]{2}{*}{ Course } & \multicolumn{3}{|c|}{ Two-year } & \multicolumn{3}{|c|}{ Four-year } & \multicolumn{3}{|c|}{ Two- and four-year } \\
\hline & R-GE & $\mathrm{R}-\mathrm{A}$ & $\mathrm{E}$ & R-GE & $\mathrm{R}-\mathrm{A}$ & $\mathrm{E}$ & R-GE & R-A & $\mathrm{E}$ \\
\hline $\begin{array}{l}\text { Basic } \\
\text { (freshman) } \\
\text { grammar }^{\mathrm{a}}\end{array}$ & 12 & 2 & 1 & 16 & 0 & 0 & 1 & 0 & 0 \\
\hline $\begin{array}{l}\text { Basic } \\
\text { (freshman) } \\
\text { composition }^{\mathrm{a}}\end{array}$ & 15 & 2 & 0 & 20 & 0 & 0 & 0 & 0 & 0 \\
\hline $\begin{array}{l}\text { Advanced } \\
\text { composition }^{\mathrm{a}}\end{array}$ & 5 & 2 & 7 & 16 & 0 & 3 & 0 & 0 & 0 \\
\hline Speech $^{\mathrm{a}}$ & 10 & 4 & 3 & 16 & 0 & 2 & 1 & 0 & 0 \\
\hline Debate & 0 & 0 & 6 & 1 & 0 & 4 & 0 & 0 & 0 \\
\hline $\begin{array}{l}\text { Interpersonal } \\
\text { communication }\end{array}$ & 1 & 1 & 7 & 8 & 1 & 4 & 0 & 0 & 0 \\
\hline $\begin{array}{l}\text { Basic } \\
\text { Computing }^{\mathrm{b}}\end{array}$ & 8 & 2 & 4 & 16 & 2 & 4 & 1 & 0 & 0 \\
\hline
\end{tabular}


Table 3

Additional Coursework Used to Address Communication Training

\begin{tabular}{|c|c|c|c|c|}
\hline & $\begin{array}{l}\text { Two-year } \\
\text { institution }\end{array}$ & $\begin{array}{l}\text { Four-year } \\
\text { institution }\end{array}$ & $\begin{array}{l}\text { Two- and } \\
\text { four-year } \\
\text { institution }\end{array}$ & Total \\
\hline Dedicated course & 1 & 3 & 0 & 4 \\
\hline Course unit & 15 & 18 & 0 & 33 \\
\hline One-on-one training & 7 & 11 & 0 & 18 \\
\hline Commercial videos & 10 & 8 & 0 & 18 \\
\hline Self-study & 8 & 6 & 1 & 15 \\
\hline Other & 1 & 3 & 1 & 4 \\
\hline \multirow{3}{*}{\multicolumn{5}{|c|}{$\begin{array}{l}\text { Note: Of } 37 \text { total respondents, } 16 \text { indicated affiliation with a two-year institution, } 20 \text { indicate } \\
\text { institution, and one indicated both. } \\
\text { Table } 4 \\
\text { Methods Used to Teach/Practice Communication: Two-year Versus Four-year Institutions }\end{array}$}} \\
\hline & & & & \\
\hline & & & & \\
\hline & $\begin{array}{l}\text { Two-year } \\
\text { institution }\end{array}$ & $\begin{array}{l}\text { Four-year } \\
\text { institution }\end{array}$ & $\begin{array}{l}\text { Two- and four- } \\
\text { year institution }\end{array}$ & Total \\
\hline Written exercises & 11 & 18 & 1 & 30 \\
\hline Oral presentations & 14 & 18 & 1 & 33 \\
\hline Group exercises & 11 & 15 & 0 & 26 \\
\hline In-class discussion & 14 & 19 & 0 & 33 \\
\hline $\begin{array}{l}\text { Computer-based } \\
\text { exercises }\end{array}$ & 4 & 9 & 0 & 13 \\
\hline Other & 1 & 1 & 0 & 2 \\
\hline
\end{tabular}


Table 5

Use of Writing Assignments: Two-year Versus Four-year Institutions

\begin{tabular}{lcccc}
\hline & $\begin{array}{c}\text { Two-year } \\
\text { institution }\end{array}$ & $\begin{array}{l}\text { Four-year } \\
\text { institution }\end{array}$ & $\begin{array}{c}\text { Two- and four- } \\
\text { year institution }\end{array}$ & Total \\
\hline $\begin{array}{l}\text { Require writing } \\
\begin{array}{l}\text { assignments in } \\
\text { aviation courses }\end{array}\end{array}$ & 14 & 20 & 1 & 35 \\
$\begin{array}{l}\text { Require multiple } \\
\text { drafts of at least one }\end{array}$ & 3 & 8 & 0 & 11 \\
$\begin{array}{l}\text { writing assignment } \\
\begin{array}{l}\text { Base a percentage of a } \\
\text { course grade on } \\
\text { writing assignments }\end{array}\end{array}$ & 9 & 17 & 1 & 27 \\
\end{tabular}

Note: Of 37 total respondents, 16 indicated affiliation with a two-year institution, 20 indicated a four-year institution, and one indicated both. 
Table 6

Writing Assignments Reported: Two-year Versus Four-year Institutions

Two-year Four-year Two- and four- Total

institution institution year institution

General assignments

Article summary

7

14

1

22

Book report

10

11

1

22

Department/unit annual

0

1

0

1 report

Expense report

1

1

0

2

Journal

2

13

0

15

Library research report

10

17

1

28

Ungraded writing

3

8

0

11

assignment

Aviation specific

assignments

\begin{tabular}{|c|c|c|c|c|}
\hline Accident report & 8 & 13 & 0 & 21 \\
\hline $\begin{array}{l}\text { Aircraft purchase } \\
\text { proposal }\end{array}$ & 0 & 3 & 1 & 4 \\
\hline $\begin{array}{l}\text { Airport planning } \\
\text { document }\end{array}$ & 3 & 11 & 1 & 15 \\
\hline Flight log & 4 & 10 & 0 & 14 \\
\hline Incident report & 3 & 10 & 0 & 13 \\
\hline Maintenance report & 1 & 3 & 0 & 4 \\
\hline Other & 4 & 3 & 0 & 7 \\
\hline
\end{tabular}


Table 7

Status of WAC Programs: Two-year Versus Four-year Institutions

\begin{tabular}{lccc}
\hline & Two-year institution & Four-year institution & $\begin{array}{c}\text { Two- and four-year } \\
\text { institution }\end{array}$ \\
\hline No WAC & 13 & 9 & 1 \\
WAC in development & 1 & 3 & 0 \\
$\begin{array}{l}\text { Established WAC } \\
\text { program }\end{array}$ & 2 & 8 & 0 \\
\hline
\end{tabular}

